\title{
Alternative Co-Teaching in Practical Lesson to Teach Speaking at SMK-SMTI Pontianak
}

\author{
Marwandi \\ Universitas Tanjungpura \\ lisajulianti@ymail.com \\ Y. Gatot Sutapa \\ Universitas Tanjungpura \\ yohanes.gatot.sutapa.y@fkip.untan.ac.id \\ Urai Salam \\ Universitas Tanjungpura \\ uray.salam@fkip.untan.ac.id
}

\begin{abstract}
This paper was a classroom action research aiming at answering and finding out on how the implementation and how teachers' collaboration through alternative co-teaching improved the students' speaking in grammar, pronunciation, fluency, and process explanation at Vocational High School (SMK) SMTI Pontianak. This study involved 28 students from Year - 11 students of academic year 2016/2017. The data were collected through observation, field note, questionnaire and test. The result indicated that the use of microphone and speaker were needed to avoid noise level in the workshop and keep the quality of the students' speaking tests better and clear. The productive teacher used bilingual during briefing; especially technical words related to parts of the machine, personal protective equipment, and process of making a product. The students were able to describe the machine used including parts and its functions, personal protective equipment, and process of making a product based on the job sheet given by the productive teacher. Alternative co-teaching in practical lesson also helped the students to describe process fluently, accurately, and grammatically. Moreover, the students have more time to practice English orally in practical lesson where the teaching hour is three times longer than the regular English classroom.
\end{abstract}

Keywords: Collaboration, Alternative Co-teaching, Practical lesson

\section{INTRODUCTION}

The curriculum of 2006s was designed in some approaches; academic, life skills, competencybased curriculum, broad based curriculum, and production based curriculum. The material for basic vocational competency is adjusted to the need of expertise to meet the standard of working competency at working sector. Therefore, SMK SMTI is using the curriculum of 2006.

Likewise, Vocational Education and Education Training (VET) requires its students to learn English inside the classroom. Its curriculum states seven competences that should be achieved by Year - 11 students of Class B in order to complete the course; understanding simple daily conversations in professional and non-professional contexts with non-native speakers, understanding simple messages through direct and indirect communication, describing jobs and background of 
studies both written and orally, describing past events and future working plans, expressing different kinds of intention, understanding simple instruction and manuals/SOPs, and understanding and writing short messages, instructions and directions using correct words and punctuation. All of those competences are real life use and related to the skills they need after graduating from the school to promote their jobs.

However, problems are identified during English learning at VET. It lies on lack of speaking skills. There are several reasons why speaking skills in English language learning are rather difficult for Year - 11 students of Class B of SMK-SMTI Pontianak. First, the use of power point and lecturing model in delivering materials for the students were previously preferred by the teacher to achieve the competencies established in the curriculum. As the result, $74.01 \%$ of the Year -11 students of Class B have lack of interest in English due to the teaching technique used by the teacher. Second, having lack of vocabularies related to the students' major and lack of opportunity to practice resulting $37 \%$ of the students claimed that speaking were their main obstacles in learning English. Meanwhile $25.93 \%$ is listening and $3.7 \%$ is writing. It means that after they graduate from the school, speaking skill is used more to promote their job than other language skills; listening and writing. Therefore, teaching English as a foreign language requires the use of effective learning methods, techniques, or activities promoting the speaking.

Based on the researcher's observation, traditionally vocational English language teaching in SMK-SMTI Pontianak for Year - 11 students of Class B is still based on teacher-centered where it sometimes neglects the students' participation in the classroom actively. The demand for speaking skill, especially English related to the students' major (92.59\%) are needed.

Moreover, the limitation of English teaching hours based on the national curriculum for the Year - 11 students of Class B is four hours of teaching in a week to complete seven competences in one year; four competences in first semester and three competences in second semester. Thus, it will affect the chance for the students to practice shorter than usual and even will not achieve the teaching and learning goals planned. In speaking test for understanding simple instruction and manuals/SOPs the teacher usually asks the students to make a presentation of power point in a group of 4 or 5 students in the classroom and they are scored based on the group presentation. In delivering the presentation, the students tend to see the power point presented rather than understand the materials being presented.

Therefore, English language teachers in this case should create a unique style of teaching by conducting teachers' collaboration through alternative co-teaching between English teacher and productive teacher during practical lesson in the workshop or laboratory in order to have more opportunities to practice and also prepare the students for ASEAN Economic Community. The alternative co-teaching in this context is partnering of productive subject teacher and English language subject teacher who share the class, the students, instructional materials, and authority to achieve the goals. The co-teaching model is conducted in mechanical engineering workshop during the practical lesson.

Similar research about parent - school personnel collaboration (McCarthy, Brennan, \& Vecchiarello, 2011), co-teaching between ESL teacher and general education teacher (Honigsfeld \& Dove, 2010), native English teacher - non native English teacher collaboration (You, 2015), NETs and NNETs in Chinese primary schools (Liu, 2008), had been conducted where both teachers appear in the same time in one classroom to deliver the instructional materials. All of them are resulting better teaching effect and improve the students' achievements. To this researcher's knowledge, no studies have been done yet on teachers' collaboration through alternative co-teaching between English language teacher and productive teacher in vocational high school (SMK) in workshop. Thus, this research fills in this gap in the literature by focusing on such collaboration for Year - 11 students of Class B in SMK- SMTI Pontianak. 


\section{METHOD}

Classroom action research modified from Kemmis, McTaggart, \& Nixon design (2014) was used as the research design. Since classroom action research aims how to improve the teachers' own practices (Kemmis, McTaggart, \& Nixon, 2014) especially in the classroom process, school curriculum, evaluation, and parent participation (Grey, 2004), the researcher in this case improved the students' speaking skills in describing process through alternative co-teaching in two cycles in which each cycle consisted of four phases; planning, acting, observing, and reflecting.

The subject of the study was the Year - 11 students of Class B of SMK-SMTI Pontianak in academic year 2016/2017 consisted of twenty eight mechanical engineering male students. The researcher decided to take this class as a sample because the students found difficulties in practicing their speaking from the previous reflection.

In the planning phase, both English language and productive teachers integrated the materials which were related to the syllabus to design the lesson plan. In this phase also, the field note, posttest and observation checklist for the teacher and the students were prepared.

In the acting phase the researcher gathers evidence needed for the research in the classroom. In acting phase of classroom action study, there were three main parts used in the classroom activity; pre-activity, whilst- activity, and post-activity. The first meeting was in English language class where the English language teacher explained about the objectives of the lessons learnt and gave the assignment to the students to do a monolog about simple instruction in describing a process and manuals/SOPs of machine. In the second meeting, it was in the mechanical engineering workshop during the practical of productive lesson hour. Before starting the class, the students were given a short briefing about safety induction and explained about the job sheet and operation plan to do. Both productive and English language teachers appeared in the same time. After briefing, the students were separated into two, 14 students practiced to make the product with productive teacher, meanwhile the other 14 students were handled by the English language teacher for alternative purposes.

The researcher observed the students' achievement by using speaking rubric. Meanwhile the observation checklist was used by the collaborator to investigate and evaluate the implementation of alternative co-teaching during teaching and learning process. The information obtained from the acting phase during the teaching and learning process was very useful to recognize the effect of the treatment given. The quantitative data covered the results from teacher's observation checklist done by collaborator and the students' progress based on the students' speaking score while the qualitative data comprised the students' interest and responses toward English teaching in preliminary research.

The tools of data collection used were teacher's observation checklist, field note, questionnaire, test and audio video recording. All data gathered from observation sheet, field note, and questionnaire were compared, contrasted, and cross checked to support the findings of the research. The researcher designed the procedures of teaching into lesson plan then implements them in two cycles. The changing of the procedures in cycles was reported in the field note. The researcher conducted interrater reliability; the researcher and the collaborator were the raters for the students' speaking test. The classroom observations in this research were done by colleague to observe the aspects of teaching practice and students' involvement in the teaching and learning activities. The observation checklist was modified from instrument of teaching and learning activity supervision at SMK-SMTI Pontianak. The speaking test was conducted in mechanical engineering workshop individually and used to find out the students' progress or change from cycle to another cycle. Questionnaire was used before and after the alternative co-teaching conducted to find out the students' response. Meanwhile, audio video recording was used to record in detail every moment due to the limitation of the researcher.

After collecting the data, the researcher analyzed the data of teaching and learning process. Then, the researcher reflected himself by seeing the result of the observation, whether the teaching and learning process of speaking through alternative co-teaching was good to apply for Year- 11 students of Class B of SMK-SMTI Pontianak or not. If the first plan was unsuccessful, proven by the 
students' achievement, the researcher made the next plan (re-planning) to solve the students' problems until the alternative co-teaching improved the students' speaking score and the teacher's technique in implementing it.

\section{RESULTS AND DISCUSSIONS}

\section{Results}

The research was conducted in two cycles and every cycle consisted of two meetings; 1 meeting in the classroom and 1 meeting in the workshop. In the first cycle, few unexpected things happened during the implementation of alternative co-teaching whether in the classroom or in the workshop. The teacher missed few things in his teaching practice. First, the teacher did not explain material clearly about how to describe process. The teacher only asked the students to include about personal protective equipment, the parts of the machine used, and the process how to make a product in their explanation without telling in details how to do it. Second, the teacher spent too much time in task 2 in the classroom by reading a loud the text for 3 times so that the students could fill in the blanks provided. Moreover, the students also spent too much time to memorize the material about describing process in the workshop. Therefore, the time allocation was not very successfully arranged. Third, the teacher did not use microphone and speaker for the students in conducting oral test in the workshop. The noise level was quite high during the practical lesson in the workshop. Thus, it affected the quality of the students' audio and video. Last, the teacher summarized the material by himself. The teacher forgot to involve the students in summarizing the material learnt and inform the next meeting material

There were 3 students who were absent in cycle 1 because of being sick. Therefore, only 25 students were tested. Some students had also lack of pronunciation for certain words related to the personal protective equipment, parts of the machine, and the process how to make it such as; function, work piece, thread, machine, wear pack, lathe, and groove. Only 4 students (16\%) who explained in detail covering three aspects; personal protective equipment and their functions, parts of the machine and their functions, and the process. There were 14 students (56\%) explaining 2 out of 3 aspects and 4 students (16\%) explaining 1 out of 3 aspects. And there were 3 students (12\%) who only mentioned one of three aspects required.

After acting out and observing the teaching practice, the researcher and collaborator teacher reflected on the practice and plan for the next cycle. From the reflection, there were some issues in cycle 1 which should be revised for the betterment of teaching and learning process in cycle 2 . Both researcher and the collaborator teacher agreed to solve the following problems found in cycle 1 .

In the second cycle, there was only 1 student who was absent in cycle 2 because of being sick. Therefore, 27 students were successfully tested. In this cycle, the teacher had explained the materials clearly and managed the time very well in every task conducted. The tasks were designed to help the students to be easy to describe process in the workshop. Drills and repetitions related to the personal protective equipment, parts of the machine, and the process how to make a product both in the classroom and in the workshop were done by the teacher to ease the students to comprehend the materials. The teacher also used microphone and speaker in the workshop to maintain the quality of the audio during the test and for the scoring. The productive teacher used bilingual for the words intended in his teaching learning process in the workshop, such as for the parts of the machine, job sheet given and the technical terms related to their major. For the last activity, the teacher involved the students to summarize the materials taught.

There were 24 students $(88.89 \%)$ who explained in detail covering three aspects: personal protective equipment and their functions, parts of the machine and their functions, and the process. There were only 3 students $(11.11 \%)$ explaining 2 out of 3 aspects and none of the students $(0 \%)$ explaining 1 out of 3 aspects or only mention one of three aspects required.

After conducting cycle 2, the researcher and collaborator teacher reflected on the practice again. From the reflection, the teacher and the collaborator teacher found out that the students had already made some improvements in their scores. It happened due to the improvement of the teaching and learning process from cycle 1 to cycle 2 . Based on the problems identified in cycle 1 , the teacher had 
revised the process well. Starting with explaining the material clearly in order to be understood by the students, arranging tasks carefully with the activities conducted to help the students to overcome their problems, involving the students to summarize the lesson, using microphone and speaker to make audio quality better, involving the productive teacher to use bilingual in the practical lesson and doing drills and repetitions in every meeting more often. He did not repeat his mistakes in cycle 1; not explaining the material clearly, spending too much time in one activity, forgetting to involve students in summarizing the lesson, and not using microphone and speaker to record the audio.

Table 1. Problems in Cycle 1 and Their Solutions

\begin{tabular}{ll}
\hline \multicolumn{1}{c}{ Problems } & \multicolumn{1}{c}{ Solutions } \\
\hline The teacher did not explain material clearly about & $\begin{array}{l}\text { The teacher explained } \\
\text { material clearly about } \\
\text { how to describe process. }\end{array}$ \\
including personal \\
protective equipment \\
and their functions, parts \\
of the machine and their \\
functions, and the \\
process how to make a \\
product.
\end{tabular}

The teacher spent too much time in certain activity.

The teacher arranged the time well especially in the classroom from the first activity to the last activity.

Students' lack of time to prepare and memorize the material about describing process to be presented in the workshop.
The teacher designed the tasks which were related to the describing process topic; lathe and milling machine parts and functions, kinds of personal protective equipment in the workshop and their functions.

The noise level was quite high in the workshop to conduct oral test.

The use of microphone and speaker were needed for a clear and better quality of the oral test audio. 
The teacher forgot to involve the students in summarizing the material learnt and inform the next meeting material.
The teacher involved the students in summarizing the material learnt and informed next meeting material.
Students' lack of grammar especially in simple basic tenses, the use of modals, to infinitive, V1 in procedure text.
The teacher designed the tasks which helped the students to construct correct sentence to explain about the machine and PPE.
Students' lack of pronunciation for certain words related to the personal protective equipment, parts of the machine, and the process how to make a product.
The teacher gave drills and repetitions words related to the personal protective equipment, parts of the machine, and the process how to make a product both in the classroom and in the workshop. The productive teacher used bilingual for the words intended in his teaching learning process.
The teacher designed the tasks which helped the students to understand materials about parts of machine including their functions, and PPE.

Therefore, the teacher and the collaborator teacher decided to stop in cycle 2 because it had already revised some weaknesses of cycle 1 and the students had shown well progress in their speaking especially in describing process. For example in cycle 1, the students explained only 2 out of 3 aspects required, but most students could explain 3 aspects required in cycle 2 . Furthermore, the word count calculation in cycle 2 showed that most students spoke more and detail than cycle 1 .

\section{Discussion}

The researcher found that teachers' collaboration through alternative co-teaching improved the students' speaking about describing process to Year - 11 students of Class B at Vocational High School (SMK) SMTI Pontianak.

First, the students made mistakes commonly in constructing a sentence based on the correct tenses in cycle 1 (e.g.: I am here today is to describing the operation plan for this ..., Today, I will to 
tell you about ..., We feeding the work piece ...). Moreover, the researcher also found the use of grammar pattern errors (eg: to + Ving, Modals + Ving, Modals + to + VI, S + Ving, S + to be +VI). The other mistakes were about explaining the procedures (e.g.: First, using safety ... Then, setting ... ...). In cycle 2, the researcher designed the tasks which were easily used by the students to mention and explain the parts, functions, and the process of how to make a product orally, including how to construct simple sentence by using simple tenses to minimize the mistakes above.

Second, some students mispronounced especially the words related to parts of the machine and personal protective equipment in cycle 1 (e.g.: thread, machine, lathe, work piece, cutting, function). But in cycle 2, the productive teacher had already used bilingual to help the students' pronunciation for certain words related to their materials such as parts of the machine, personal protective equipment, and the job sheet given. Drills and repetitions were also done more often to make students' pronunciation better in every meeting, especially for the words related to parts of the machine and personal protective equipment. As a result, the students' pronunciations were better in cycle 2 .

Third, the students were difficult to describe the process in English due to the time limitation given to memorize. They needed extra works to memorize what they wanted to explain. Therefore, the students had some false starts, pauses or hesitations during the speaking test. In cycle 2, the students just reviewed and looked up their tasks in the first meeting to remember a bit about what had been learnt as their materials to describe a process in the workshop. Besides, the use of real media such as: real lathe or milling machine and personal protective equipment in the workshop helped the students to be fluent in describing process.

There were 24 students $(88.89 \%)$ successfully explained in detail covering three aspects; personal protective equipment and their functions, parts of the machine and their functions, and the process in cycle 2. In this cycle also, 7 students were improved in grammar aspect, 5 students were improved in pronunciation aspect, 6 students were improved in fluency aspect, 19 students were improved in content aspect, and 26 students were improved in their word count when talking. The more words the students produced, the more mistakes they made in grammar, pronunciation, or fluency. So in this case, there was a correlation between the students' mistakes and the students' word count as well. Therefore, the researcher should revise the instruction for speaking test in the future in order to limit the word count produced by the students.

Based on the students' responses toward the questionnaire, there were 4 students $(15.38 \%)$ who stated that the lesson was difficult due to the noise level and technical English. While the other students stated that the lesson was exciting (23.07\%); easy to explain due to real media use in the workshop, useful (30.76\%); for their job in the future, and fun (30.76\%); presenting in the workshop by using English. Among the other activities provided by the teacher during the teaching learning process, most students $(96.15 \%)$ preferred the activity of presenting in the workshop to learning in the conventional classroom $(3.85 \%)$.

Table 2. Schematic Table of Year - 11 Students' Questionnaire at SMK-SMTI Pontianak

\begin{tabular}{ccc}
\hline $\begin{array}{c}\text { Question } \\
\text { Number }\end{array}$ & Answer & Percentage \\
& & \\
& Difficult & $15.38 \%(4)$ \\
1 & Exciting & $23.07 \%(6)$ \\
& Useful & $30.76 \%(8)$ \\
& Fun & $30.76 \%(8)$ \\
2 & Presenting in the Workshop & $96.15 \%$ \\
2 & Learning in the Classroom & $(25)$ \\
\hline
\end{tabular}




\begin{tabular}{|c|c|c|}
\hline & & $3.85 \%(1)$ \\
\hline & $\begin{array}{c}\text { Easy to explain } \\
\text { ESP } \\
\text { Others }\end{array}$ & $\begin{array}{c}53.85 \% \\
(14) \\
30.77 \%(8) \\
15.38 \%(4)\end{array}$ \\
\hline 3 & $\begin{array}{l}\text { Noise level } \\
\text { Time limitation } \\
\text { Text based } \\
\text { Others }\end{array}$ & $\begin{array}{c}19.23 \%(5) \\
42.31 \% \\
(11) \\
15.38 \%(4) \\
23.08 \%(6)\end{array}$ \\
\hline 4 & $\begin{array}{c}\text { Yes (for working, English } \\
\text { text book etc.) } \\
\text { No }\end{array}$ & $\begin{array}{c}100 \%(26) \\
0 \%\end{array}$ \\
\hline 5 & $\begin{array}{c}\text { Opening and closing } \\
\text { presentation } \\
\text { Mentioning parts of } \\
\text { machine and their functions } \\
\text { Explaining production } \\
\text { process }\end{array}$ & $\begin{array}{c}69.23 \% \\
(18)\end{array}$ \\
\hline
\end{tabular}

Learning in the practical lesson through co-teaching had some advantages. As what has been explained in Chapter 2 that co-teaching is like a marriage (Honigsfeld \& Dove, 2010) where two heads are better (Stark, 2015). The co-teaching implemented in fact, helped the students to improve their speaking ability which were authentic (Lazaraton, 2001) and related to their major. During the implementation in the mechanical engineering workshop at SMK-SMTI Pontianak, the class number was smaller than the conventional one (Howe, 2005). Moreover, the students felt easy to explain the process $(53.85 \%)$ since the real media use in the workshop. The tasks were aligned with their productive lesson tasks based on the job sheet given to produce a product as well. Therefore, the students needed English for Specific Purpose in the future to support their job (30.77\%).

However, the implementation of alternative co-teaching in the workshop also had disadvantages. During the practical lesson in the workshop, the noise level was high (19.23\%). It was caused by the sound of machines and other equipment. This noise level was revised in cycle 2 where the teacher provided microphone and speaker for the speaking test to keep the audio quality better. Some students $(15.38 \%)$ were still text based in presenting how to describe a process. While the others $(42.31 \%)$ felt the time was not enough to do. All students (100\%) agreed that English related to their major was useful for their future job and English textbook understanding.

In conclusion, the alternative co-teaching implemented helped the students to improve their speaking ability which were authentic and related to their major. Some efforts to revise the teaching learning process had been done in order to get better results. Yet, the students thought that speaking was hard to do but on the contrary, speaking was needed in the future. 


\section{CONCLUSION AND SUGGESTION \\ Conclusion}

Based on the discussion of the previous chapter, it can be concluded that alternative co-teaching in practical lesson improved the students' abilities to describe process from cycle to cycle. They are used for the students to explain and describe about the process when they are in the real working situation of a company in the future. During the alternative co-teaching implementation, the use of microphone and speaker were needed to avoid the noise level in the workshop and keep the quality of the students' oral tests better and clear. The productive teacher used bilingual during the briefing; technical words related to the parts of the machine, personal protective equipment, and process.

In this research, alternative co-teaching in practical lesson helped the students to improve their speaking skills in describing process. The students were able to describe the machine used including the parts and its functions, personal protective equipment, and the process of making a product based on the job sheet given by the productive teacher.

Alternative co-teaching in practical lesson also helped the students to describe process fluently, accurately, and grammatically. Moreover, the students have more time to practice English orally in practical lesson where the teaching hour is three times longer than regular English classroom.

\section{Suggestion}

There are several suggestions considered to enhance the co-teaching effect in teaching learning process: 1) the job distributions between English teacher and productive teacher should be well managed and agreed in the initial stage of the implementation of co-teaching. 2) the teacher should explain more clearly the material to the students with the examples and how to do it considering that the implementation of co-teaching involves two different subjects and teachers. 3) the teacher should design the tasks well to help the students to overcome their problems in speaking. 4) the teacher should consider the use of media such as microphone and speaker to keep the quality of the students' speaking audio better in scoring the results and involve the students' in summarizing the lesson. 5) teachers' collaboration through alternative co-teaching could be used for teaching the other skill as well, such as writing.

\section{REFERENCES}

Grey, D. E. (2004). Doing Research in the Real World. London: Sage.

Honigsfeld, A., \& Dove, M. G. (2010). Collaboration and Co-Teaching: Strategies for English Learners. London: Corwin A SAGE Company.

Howe, A. (2005). Perspective in Oracy. Dalam S. Brindley, Teaching English (pp. 38-47). New York: Routledge.

Kemmis, S., McTaggart, R., \& Nixon, R. (2014). The Action Research Planner: Doing Critical Participatory Action Research. Singapore: Springer.

Lazaraton, A. (2001). Teaching Oral Skills. In M. Celce-Murcia, Teaching English as a Second or Foreign Language (pp. 110-112). Bosotn: Heinle \& Heinle.

McCarthy, P. J., Brennan, L., \& Vecchiarello, K. (2011). Parent - School Communicationin the Inclusive Room: A Comprehensive Model of Collaboration in Education. International Journal of Humanities and Social Science, Vol 1, pp. 55-60.

Stark, E. (2015). Co-teaching: the Benefits and Disadvantages. Journal on Best Teaching Practices, Vol 2, pp. 7-8.

You, H. (2015). Personalized College English Teaching Based on Collaboration among Teachers. International Journal of English Language Teaching, Vol 2, pp. 40-44. 